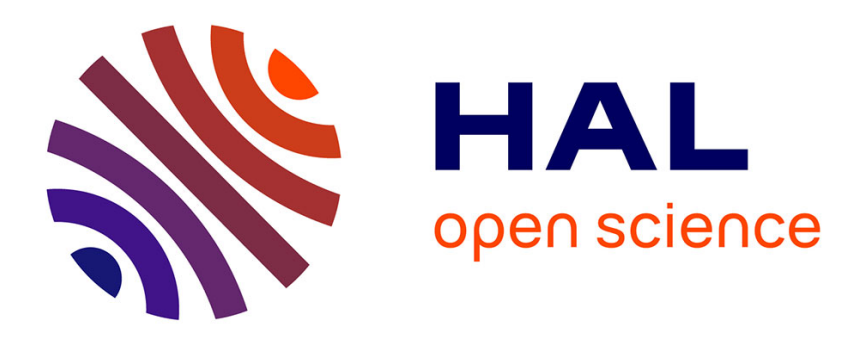

\title{
Working Process for Superconductors by Means of HERF-Technique
}

\author{
N. Göbl, A. Szalay
}

\section{To cite this version:}

N. Göbl, A. Szalay. Working Process for Superconductors by Means of HERF-Technique. Journal de Physique IV Proceedings, 1997, 07 (C3), pp.C3-39-C3-44. 10.1051/jp4:1997309 . jpa-00255382

\section{HAL Id: jpa-00255382 https://hal.science/jpa-00255382}

Submitted on 1 Jan 1997

HAL is a multi-disciplinary open access archive for the deposit and dissemination of scientific research documents, whether they are published or not. The documents may come from teaching and research institutions in France or abroad, or from public or private research centers.
L'archive ouverte pluridisciplinaire HAL, est destinée au dépôt et à la diffusion de documents scientifiques de niveau recherche, publiés ou non, émanant des établissements d'enseignement et de recherche français ou étrangers, des laboratoires publics ou privés. 


\title{
Working Process for Superconductors by Means of HERF-Technique
}

\author{
N. Göbl and A. Szalay
}

Metalltech R\&D Ltd, Vas Gereben u. 27., 1124 Budapest, Hungary

\begin{abstract}
At the production of superconductors the compaction of powderform raw materials can be made by means of HERF (High Energy Rate Forming) "powder in tube" techniques, too. The compacting processes of the powders in the metal tubes fitted with metal cores were tested by the authors in the cases of explosive and electromagnetic formings. In order to compare the compacted material structures in the cases of both forming methods were applied cylindrical samples with the same layout. The results of the compacting processes were estimated as functions of the forming parameters. It has been found, that the most favourable grain structures could be realized in the narrow path of forming velocities which are on the given construction of samples typical. The manufacture of semi-products of superconductors can be carried out by means of explosive technology in practice economical, because thespecific costs of electromagnetic forming with large equipments are much more than the costs of explosive forming process with the same energy level.
\end{abstract}

\begin{abstract}
Résumé: Le compactage de la poudre au cours de la production des materiaux supraconductibles par la methode "poudre dans le tube" on peut realiser avec l'aide de la HERF-Technique (Formage technique á haute energie ou á grande vitesse). Les auteures ont passé l'exame des procedes de compactage de la poudre dans le tube metallique avec barre roude metallique en cas de formage explosive ainsi que en cas de formage electromagnetique. Afin qu'ils puissent comparer les structures materielles compactes dans les deux cas de formage technique ayant mis en practique test-objétes cylindriques avec arrangement égale. Les resultates des procedés de compactage sont representé en fonctions des parametres de formage. Par consequent, les structures des plus avantegeuses grains on pouvait réaliser dans un intervalle restreint qui sont caracteristique de construction des test-objectes. La fabrication des demi-produits des produits supraconductibles en cas de formage explosive est dans la practique plus economique parce que les frais specifiques de la formage electromagnetique avec installations grandes plus que les frais specifiques de la formage explosive en cas de energie égale.
\end{abstract}

\section{INTRODUCTION}

The dynamic powder-compaction processes have been used worldwide for manufacturing of different products for more than fifty years [1].

The discovery of the high temperature superconductors (HTSC) in 1986 promised the revolution of the electrical industry. These materials are able to conduct the electrical current without energy losses as they have no resistance. On the other side they have special magnetic properties which are very promising from point of construction of frictionless bearings, clutches etc. The fundamental problem with these materials is however, that they are ceramics. The HTSC raw materials are produced in the form of ceramic powders with the characteristic compositions of $\mathrm{YBaCuO}$ and $\mathrm{BiCaCuO}$.

For practical application of the HTSC materials a lot of processing techniques (static and isostatic pressing, thick layer technique, plasma-spray, etc.) have been tested and applied. One of the most frequently applied technique for production of HTSC wires is the "powder in tube" technique [2]-[4]. That means, both the explosive and the electromagnetic powdercompation will have important role in the development and production of the superconducting parts and equipments. 
Why dynamic compaction? We consider the explosive and electromagnetic compaction techniques as a tool to obtain ceramics with unique properties [2],[3],[5]. The advantages of the dynamic compaction over conventional compaction techniques are the relatively low bulk temperature and the very high pressures acting on powders or granulates.

- the low bulk temperature has a great importance in the case of fabrication of ceramic-metal compositions, where the metals are in the form of tube, sheet or wire. As the coefficient of thermal expansion of silver is approximately 1,5 times higher than that of $\mathrm{YBaCuO}$ ceramic [7], we can create bondings between the ceramics and the metals with a minimum residual stress when the bonding is created at the lowest possible temperature.

- The very high pressures in the range of 1-10 GPa make it possible to affect the microstructure of the compacts on the one hand, and make it possible to create good metal-ceramic bondings between the metal sheath and the HTSC ceramic and/or between the embedded metal contact rods and the HTSC ceramic

We have applied two kinds of explosive compaction: the explosive "powder-in-tube" and the electromagnetic "powder in tube" techniques. The principles and the practical details of the two different techniques were described in our previous papers [6], [8], [10].

The above mentioned two dynamic powdercompaction technologies show significant differences from point of both the effect-mechanisms and the values of the applied energies. Our aim was to compare and analyse the material structures and the superconducting properties of the test samples produced by the two technologies. For the possible correct comparison we took into account the followings:

-The composition, the grain size and the initial density of the HTSC ceramic materials placed between the metal tube and the metal core were the same

-In the case of both technological experiment we applied the isodynamic compaction that is the impulseform pressure must act on the whole outer surface of the metal container containing the powder to be compacted. For this purpose we used cylindrical form test pieces with metal mandrel in their axis.

The analyse of the results of the tests were based on the examination and comparison of the parameters of the starting materials and the compacted materials. Our conclusions were based on the changes of the material structural parameters and the main superconducting parameters in the case of both the explosive and the electromagnetic powdercompaction techniques.

\section{EXPERIMENTAL}

The YBCO base HTSC material was produced by conventional chemical processes and the powderform starting material was compacted by isodynamic compaction. The term isodynamic compaction is applied to methods of compacting powders in which an impulsive pressure is applied simultaneously to all external surfaces of the powder body. We applied axisymmetric set-up both in the case of the explosive and the electromagnetic compactions, so we can speak about quasy isodynamic compactions.

\subsection{Preparation of the ceramic superconducting powders}

The starting material with the nominal composition of $\mathrm{YBa}_{2} \mathrm{Cu}_{3} \mathrm{O}_{7}$ was prepared by thermal treatment of a mixture consisting of oxides and carbonates such as $\mathrm{Y}_{2} \mathrm{O}_{3}, \mathrm{BaCO}_{3}, \mathrm{CuO}$.

The main parameters of the starting material:

- composition: $\mathrm{YBa}_{2} \mathrm{Cu}_{3} \mathrm{O}_{7}$

- grain size: $1-5 \mu \mathrm{m}$;

- critical temperature: $95 \mathrm{~K}$;

- superconducting phase composition: according to the $\mathrm{X}$-ray diffraction patterns shown in Figure 5.a. 


\subsection{Compaction of the starting materials}

\subsection{Explosive powdercompaction}

A metal tube (3) is filled with HTSC powder (2) and mantled with a layer of high explosive (4) of uniform thickness and density. After ignition of the detonator, the detonation will proceed down along the tube wall at a velocity $v_{D}$ leading to a compression of the tube and the powder closed between the tube (3) and the mandrel (1). The metal tube acts as a tubular punch. The shock wave created by the detonation of high explosive passages through powder leaving compacted material behind. The experimental set up is shown on Fig. 1.

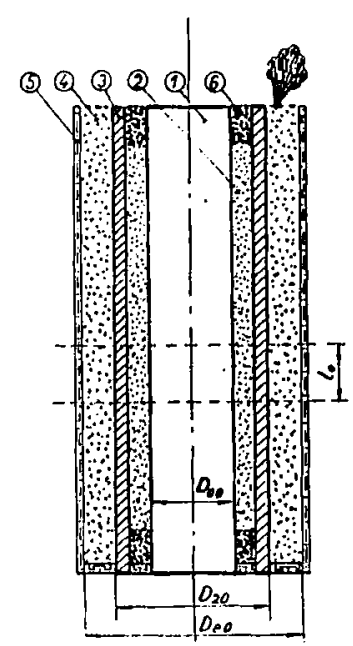

Figure 1: Experimental set up for explosive powdercompaction 1 - mandrel, 2 -superconducting powder, 3 - metal tube, 4 - high explosive, $\quad 5$-container for the high explosive, 6 - buffer powder $(\mathrm{MgO}), \mathrm{D}_{00}=11 \mathrm{~mm}, \mathrm{D}_{20}=25 \mathrm{~mm}, \mathrm{~s}=5 \mathrm{~mm}, l_{0}-$ the investigated path of section $=5 \mathrm{~mm}$

The YBCO superconducting powder was placed between a thick wall silver tube (Ag 999) and an aluminium mandrel $(\mathrm{Al} 99,5)$ and was packed to a density of about $50 \%$ of that of solid YBCO material. At both ends of the silver tube a quantity of cheap coarse $\mathrm{MgO}$ powder with a grain size of about $200 \mathrm{~mm}$ was used as a buffer in order to avoid end defects in compact. The high explosive used was 200 grams of the ammoniumnitrate base PERMON explosive with $1.1 \mathrm{~g} / \mathrm{cm}^{3}$ density and $v_{D}=3800 \mathrm{~m} / \mathrm{s}$ detonation velocity. To obtain a uniform energy distribution acting on the outer surface of the tube (starting energy of the tubular punch) we had to use a thick wall metal tube. This solution met the requirement of the minimal critical layer thickness of the high explosive used.

\subsection{Electromagnetic powdercompaction}

The alternating magnetic field of a cylindrical coil (T) induces eddy currents in the highly conductive thin wall metal tube (3) inserted inside the coil. The induced current creates another magnetic field. The effect of the interaction of these two magnetic fields will be realized in mechanical press. This pressure reduces the diameter of the tube - the tube acts as a tubular punch - and as a result compresses the HTSC powder (2) closed between the mandrel (1) and the tube (3). The strong transient magnetic field is produced by the discharge of storage capacitor bank (C) through the closed switch (S). This principle is shown schematically on Fig. 2.

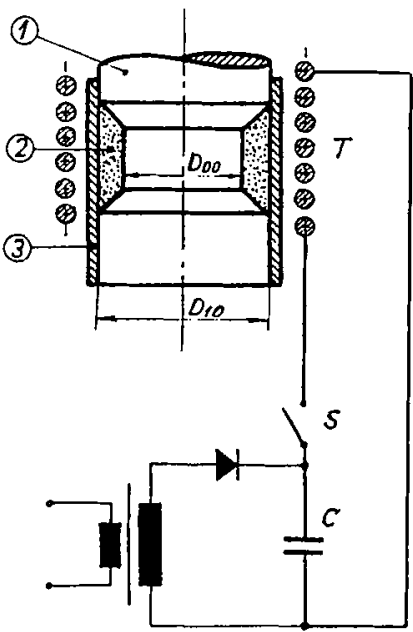

Figure 2: Principle of the electromagnetic powdercompaction 1 - mandrel, 2 - HTSC powder, 3 - metal tube, T - solenoid, $\mathrm{S}$ - switch, C - capacitor 
The cylindrical coil consisted of 12 turns made of insulated copper wire. Both the mandrel and the tube were prepared of aluminium. The density of the YBCO material before compaction was about $50 \%$ of the nominal density. The experimental set-up are shown on Fig. 3.

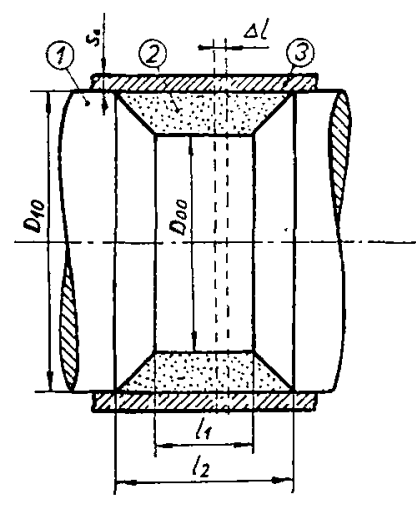

A



$\mathbf{b}$

Figure 3. Experimental set up for electromagnetic powdercompaction 1 - Al 99,5 mandrel, $2-\mathrm{Y}_{1} \mathrm{Ba}_{2} \mathrm{Cu}_{3} \mathrm{O}_{3}$ powder, $3-\mathrm{Al} 99,5$ tube a: before compaction $D_{00}=11 \mathrm{~mm}, D_{10}=15 \mathrm{~mm}, l_{1}=5 \mathrm{~mm}, l_{2}=9 \mathrm{~mm}, \mathrm{~s}_{0}=0,8 \mathrm{~mm}$ b: after compaction $\quad D_{22}=13,2 \mathrm{~mm}, s_{1}=0,85 \mathrm{~mm}$

The YBCO superconducting powder was placed between a thin wall aluminium tube $(\mathrm{Al} 99,5)$ and an aluminium mandrel $(\mathrm{Al} 99,5)$ with the initial density of about $50 \%$. We used an aluminium tube with thin wall thickness to obtain a starting energy of the tubular punch of the same order of magnitude as the one in the case of the explosive compaction. This solution met the requirement of the skin-effect, too.

\subsection{Measuring method}

\subsection{Preparation of the specimen}

The green compacts produced by electromagnetic and explosive compaction were sliced across diametral planes to examine the changes in the microstructure, the phase composition and the main superconducting parameter: the critical temperature $\left(T_{c}\right)$ of the samples. The critical temperature is the temperature, where the given conducting material having some characteristic electrical resistance, became superconducting material having zero electrical resistance.

\subsection{Measurement equipments}

- The microstructure of the samples were examined by a JEOL JSM 50A type scanning electron microscope.

- The phase composition of the samples was determined by XRD analysis. These measurements were carried out by means of a Philips-1825 type instrument.

- For controlling the critical temperature, the magnetic susceptibility was measured by a Brucker device according to Faraday's principle. 


\section{RESULTS}

\subsection{Microstructure}

The SEM photos of the electromagnetically and explosively compacted powders are shown in Fig. 4.


Figure 4: SEM photos of the examined materials (x2000)

a: the electromagnetically compacted YBCO powder b: the explosively compacted YBCO powder

The density of the electromagnetically compacted sample is about $75 \%$ of the nominal density of the YBCO material. The compaction is in the region of the "restacking" region [1]. The density of the explosively compacted sample is about $95 \%$ of the nominal density of the YBCO material. This compaction is in the region of the plastic deformation and cold working region [1].

\subsection{Phase composition}

The phase composition of the initial powder, the electromagnetically and the explosively compacted powders are shown in Fig.5.
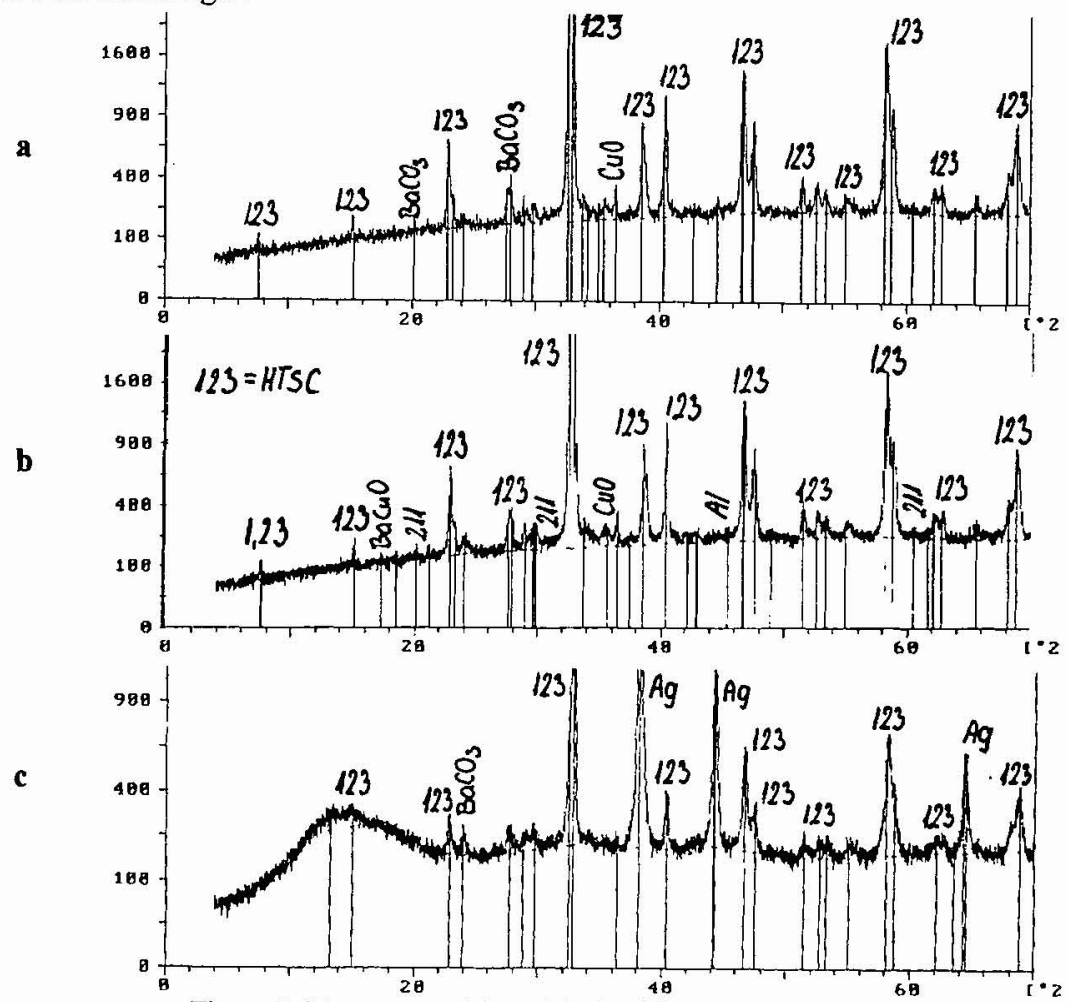

Figure 5: Phase composition of the YBCO superconducting materials

a - initial powder, b-electromagnetically compacted sample, c - explosively compacted sample 


\subsection{Critical temperature $\left(T_{c}\right)$}

The results of the susceptibility measurements are the followings:

- The critical temperature of the initial powder: $95 \mathrm{~K}$

- The critical temperature of the lectromagnetically compacted sample: $95 \mathrm{~K}$

- The critical temperature of the explosively compacted sample: $93 \mathrm{~K}$

\section{CONCLUSIONS}

- The characteristic difference between the values of the final densities and microstructures of the explosively and the electromagnetically compacted materials are mainly originated from the difference of the velocities of the shock waves generated by the two different HERF techniques.

- For more precise comparison of the affect of different compacting techniques on the structure of the compacts should apply the same specific energy acting on the HTSC powder body instead of same specific energy acting on the metal tube (i.e. the compacting punch).

- The phase composition of the initial powder were practically does not influenced by the compaction techniques.

- The electromagnetic powdercompaction technique should be considered and examined not only as a compaction process but as a method for influencing the superconducting parameters of the HTSC materials to be compacted.

\section{References}

[1] S. Clyens, W. Johnson, The dynamic compaction of powdered materials, Materials Science and Engineering 30 (1977) 121-139

[2] I.Kotsis, M. Enisz, D. Oravetz and A. Szalay, Effect of particle size and size distribution on physical characteristics, morphology and crystal structure of explosively compacted high $\mathrm{T}_{\mathrm{c}}$ superconductors. Proc. of the 4th Int. Conf. and Exhibition of the World Congress on Superconductivity, Orlando, USA, 27 June-1 July, 1994.

[3] L. E. Murr, Explosive processing of bulk superconductors. Materials and Manufacturing processes, 6, 1, 1991, 1-32.

[4] G.F. Fuente, Y.B. Huang, L.A. Angurel, A. Larrea, M.T. Ruiz, F. Lera and R. Navarro, Powderin-tube method achievments on HTSC wires and tapes. "Superconductivity in Spain" Report about MIDAS Program, Madrid, Sept. 1993. pp. 195-213.

[5] P. Boogerd and A. C. van der Steen, Microstructure of explosively compacted ceramic materials Shock-wave and high strain-rate phenomena in materials ed. M. A. Meyers, L. E. Murr and K. P. Staudhammer, M. Dekker Inc., Boston etc., 1992, pp. 443-452.

[6] N. Göbl, Unified calculating method of equivalent circuits of the electromagnetic forming tools. Dissertation for Ph.D., Technical University of Budapest, 1978.

[7] J. Echigoya, N. Hishamune, $\mathrm{H}$. Shuto, Bonding at electrical contact resistivity of $\mathrm{Ag}-\mathrm{YBa}_{2} \mathrm{Cu}_{3} \mathrm{O}_{7-x}$ joints. ISIJ International, 30, 12, 1990, pp. 1078-1085.

[8] A. G. Mamalis, G. N. Gioftsidis and A. Szalay, On the extrusion of silver sheathed superconducting billets fabricated by explosive compaction of $\mathrm{YBa}_{2} \mathrm{Cu}_{3} \mathrm{O}_{7}$ powder. J. of Materials Processing Technology, 30, 1992, 297-313.

[9] K.P. Staudhammer, Shock consolidation of $\mathrm{YBa}_{2} \mathrm{Cu}_{3} \mathrm{O}_{7-x}$ powders - powder variables. X. Int. Conf on HERF, Ljubljana, Sept. 1989, pp. 1-10.

[10] I. Vajda, L. Mohácsi, A.G. Mamalis, I. Kotsis, A. Szalay: From fabrication to application: ceramic superconductors for use in magnetically levitated bearings. Proc. of 4th Int. ECerS Conf., Riccione, Italy, October 2-6, 1995. 